\title{
Employability Skills Requirement for Technical Graduates to Face the Project-Based Employment
}

\author{
Ahmad Zubir, R. A., Yee, M. H.
}

\begin{abstract}
Competition among university graduates in gaining employment are increasing nowadays. Nevertheless, unemployment issues are increasing due to the increased in project-based employment. Project-based work is offered by a company to a group of people to complete a project designated for a specified period. Employers state that temporary hiring or project-based workers can prevent from higher costs because the recruitment of employees is according to company needs only. The difficulty in obtaining jobs and unemployment of graduates are closely related to the lack of employability skills essential because most students do not market themselves successfully in order to meet the challenge of the project-based employment. Therefore, this study aims to investigate the employability skills of students facing project-based employment. The method of this study involves the analysis of documentations on previous research to prove the importance of employability skills for students to face the project-based employment. The main finding of this study reveals that employability skills are critical for students to tackle in the working environment especially in the face of project-based jobs. Therefore, educational institutions should emphasize the needs of the industry and students by applying employability skills to students in order for them to face of project-based employment.
\end{abstract}

Index Terms: Employability skills, project-based employment.

\section{INTRODUCTION}

The country's education system today faces many challenges which demands a structural change and paradigm shifts to ensure it continues to be relevance to the country [1]. Consequently, a Malaysian Education Development Plan 2015-2025 (PPPM) was launched to drive Malaysia into a high-income developed country [2]. PPPM has outlined 10 leaps to achieve excellence in the higher education system and one of them is to produce high quality Technical and Vocational Education and Training (TVET) graduates.

TVET emphasizing the industry-wide approach to industry needs is fundamental in developing Malaysia into a high-income developed country by 2050 [3]. TVET plays a role in transforming the production of high skilled human capital and enhancing the competitiveness of the local workforce and the country's economy [1]. TVET is also expected to increase the quantity and quality of TVET

Revised Manuscript Received on September 22, 2019

Raudhah Adibah Binti Ahmad Zubir, Postgraduate Student, Technical and Vocational Education, Universiti Tun Hussein Onn Malaysia (UTHM).

Dr Yee Mei Heong, Senior Lecturer, Department of Engineering Education (JPK), Faculty of Technical and Vocational Education of Universiti Tun Husseion Onn of Malaysia (UTHM).

Siti Nur Maizura Binti Sharberi, Postgraduate Student, Technical and Vocational Education at Universiti Tun Hussein Onn Malaysia (UTHM). graduates with the aim of producing 225,000 TVET graduates by 2020 in order to achieve the agenda of providing skilled under the 11th Malaysia Plan (RMK-11).

One of the methods used to enhance the quality of graduates is the collaboration with industry to design and implement the curriculum [4]. Furthermore, involvement of employers and industry in education is essential to ensure that the knowledge and skills taught to students are appropriate and relevant to their employers' needs [5].

Today, most industries in our country provide project-based employment opportunities also known as contract work [6]. Employers who use project-based employment systems can spare on company costs as theys only need to employ only when needed [7]. Project-based work offers the opportunity for graduates to gain experience and build a reputation before getting a permanent job in the future [8]. Therefore, project-based employment is seen as a great opportunity for new graduates considering to move into the world of work. On the other hand, for employers, project-based employment is good for increasing the productivity and discipline of employees in their company [6].

Before getting a job, graduates need to equip themselves with employability skills especially in dealing with project-based employment systems. The need for employability skills among graduates is an imperative criterion for them to secure a place in the job market [9]. Employers expect their graduate to master employability skills and thus contribute to their company [10]. Therefore, graduates who have mastered employability skills and competitiveness are the choice of employers today [11]

\section{A. Unemployment Problems Among Graduates}

Unemployment and the difficulty of obtaining employment among graduates has caused anxiety for students that were still studying in higher education [12]. A survey of graduates in 2017 showed that more than 25 percent of public Higher Education Institution (IPT) are still unemployed 3 to 4 months after graduation. According to the Department of Statistics Malaysia (2018), the unemployment rate in January 2018 rose 0.1 percent to 3.4 percent. Thus reflecting that a country has high unemployment then the growth of the country is weak [13].

Graduates of IPT are now facing competition for employment both in the public and private sectors [14]. This issue of unemployment is also contributed by the project-based increase in 
employment [15]. Employers prefer hiring contract workers for services and service contracts. A statement by the President of the Congress of Workers Union in Public Services [16], revealed that there are an estimation of 60,500 of the 1.2 million workers in the public sector who are contracted or hired through project-based employment.

Nevertheless, the increased in project-based work has contributed to an increase in the number of unemployed in the country because of the attitude of graduates who are choosing jobs [17]. Most graduates fail to market themselves in terms of project-based jobs because they prefer choosing for a permanent job and reject a job that is temporary or contractual [18].

In addition, the unemployment factor is not just because of the attitude of the graduates who choose the job. Moreover, the difficulty of obtaining employment and unemployment of graduates is also related to the lack of employability skills of graduates entering the labor market [19]. The industry's feedback showed that there is a gap between the knowledge, skills and attitudes of the graduates compared to the needs of the workplace [20]. One of the gaps addressed by employers is the inability of IPT (Higher Education) graduates to master employability skills rather than technical skills [19].

Consequently, employers are dissatisfied with the employability skills of graduates in communication, leadership, critical problem solving skills, continuous learning and information management, professional ethics and morals, entrepreneurship and teamwork [14], [21], [22], [23], [24]. Most graduates who fail obtaining a job do not master employability skills, especially in dealing with project-based jobs [25].

The need for graduate to become skilled workforce in various aspects is becoming a new challenge in joining the workforce. This is because many graduates are not equipped with all the skills required by the industry today [26]. As such, it is time for the university to prepare students with special skills such as employability skills in dealing with project-based employment so that this widespread unemployment problem can be reduced in the future.

\section{PROJECT-BASED EMPLOYMENT}

Project-based employment refers to the work performed and completed for a specific project based on contract. Employees will be offered to work by a specific company for a project to be carried out for a certain period and once a project is completed, the employee will no longer work with the company [27]. Project-based employment is a job where employees are offered contract work. Contract workers are defined as laborers or workers employed for a specific task over a certain time [7]. A contract worker is also defined as an employee who is employed under a contract of employment but that employee is not hired by the company for which the employee works for him [28]. For example, the PLUS company Exspresways Berhad has appointed Propel Berhad to complete highway maintenance works. This means that the PLUS highway maintenance work is done by Propel Berhad company employees.

While, according to other sources, the term contract worker is someone who is employed and paid by the company, whose term of service has been determined and will be evaluated based on the level and progress of the employee's performance [29]. The duration of service of a contract employee in the company may be extended annually or monthly. They are also more likely to be absorbed as permanent workers or, unfortunately, dismissed. It all depends on the needs of the company and the extent to which the service is required by the company. Employees will usually terminate their contract once the project is completed successfully or their services are no longer needed by the relevant company [14].

Today, most industries in our country provide project-based employment opportunities or also known as contract work [17]. Project-based employment is an occupation in which an employee is employed according to an agreement and the term of service has been determined [7]. Employers who use project-based employment systems can save on company costs as companies need to hire only when needed [7]. Therefore, employers are only required to pay the workers' salaries according to the period in which they began working until the end of the service period [28].

Project-based employment systems are increasingly being adopted by employers, especially in the construction, electrical and mechanical industries [30] due to the industry in this field usually only needs workers during projects in progress [28]. Besides, construction industry employers are also more likely to hire new graduates to work in the project-based employment system because the cost of paying salaries to new graduates is lower than hiring experienced workers [31].

\section{A. Advantages of Project-Based Employment}

On the other hand, graduates who are smart will definitely seek opportunity and take advantage of every job prospect coming into their way. Although project-based employment is only temporary jobs, if graduates wisely seize the opportunity, they will benefit greatly [32]. This is because project-based employment provides opportunities for graduates to gain experience and build a reputation before getting permanent jobs in the future [8]. The experience gained by graduates can benefit them personally. This is because graduates with work experience are preferred by employers nowadays apart from being able to establish their maturity [33]. By gaining experience through project-based work, graduates can utilized their experience to get a better job in the future [34]. Therefore, project-based employment is seen as a great opportunity for new graduates looking to move into the world of work.

In addition, graduates can also augment and increase their interpersonal skills through project-based work [35]. A degree without a solid personality does not guarantee success in the workplace [21]. In fact, to the interview only reflects the ability to interact [36]. The experience of interacting with the public through project-based work can enhance the interpersonal ability of a graduate [37]. Therefore, well-meaning graduates should always find the opportunity to enhance their interpersonal skills to ensure they can place themselves in a better work environment.

In addition, graduates can also improve their self-discipline through project-based work. For example, graduates can manage their time better when they plan their work schedules to avoid being unemployed before the contract or 
employment agreement is over [34]. Consequently, they will be ready to search for new jobs before they complete their current employment contract. In addition, project-based work can also teach graduates to be more independent, open-minded and mature in decision making [38]. This is because graduates are less likely to choose a job because they are not unemployed and want to gain as much experience as possible before getting a full-time job.

On the other hand, for employers, project-based employment is good for increasing the productivity and discipline of employees in their company [6]. Hence when an employee is seen to be performing well, the probability of the employee being called to work again or the contract extension is high [7]. Therefore, employees will be industrious to perform their current duties during the contract period in the hope that they may be called upon to work again in the future.

\section{B. Disadvantages of Project-Based Employment}

Increased of project-based employment has contributed to the escalation in the unemployment rate in the country due to the attitude of graduates who are overly selective in choosing a job [17]. Most graduates fail to market themselves in terms of project-based jobs because they prefer to get a permanent job and reject a job that is temporary or contractual [18]. However, this is a concern given the fact that many employers today are adopting a project-based employment system because it is more profitable for the company [15].

In addition, employees who work in project-based jobs are also at high risk of being dismissed during their tenure. Employers can terminate their workers' contracts in two ways, with or without cause [14]. First, employers may terminate their employees for certain reasons. If an employee violates the rules, the project-based employment contract will be terminated. Some of these factors may be due to theft, illegal activity, fraud, violence or any other inappropriate behaviour. While the second method is for no purpose, it means that the status of the job can be terminated without any cause or action [39]. This is when an employer wants to reduce the number of employees or employees who are not eligible to work in the company.

\section{EMPLOYBILITY SKILLS}

Employability skills are non-technical skills which are important in all fields of work [40]. There are several definitions of employability skills and most of them relate to aspects of personal quality which include communication ability, confidence, responsibility, teamwork, integrity as well as the ability to handle various situations [41]. However, according to [26], employability skills related to attitude, knowledge and skills must be acquired by employees to ensure they have the ability to work.

Several previous studies stated that there are seven key components of employability skills that need to be taken into consideration by the IPT that is communication, leadership skills, critical problem solving skills, continuous learning and information management, ethics and professional ethics, entrepreneurship, and teamwork skills [14], [21], [22], [23], [24]. Most employers prefer to find a graduate who has these employability skills to employ in their company [25]. This is because employers believe that these skilled workers can adapt to all types of jobs and are versatile [42].

In line with the current trend of globalization, communication skills have become an essential aspect that employers emphasize. These communication skills include writing, reading, debating, listening, etiquette in communicating and communicating information [43]. Communication skills in both Malay and English are among the skills most graduates require especially during the interview [41]. In addition, confidence in conversation and ability to answer interview questions are also taken into account when determining whether or not the graduate is successful [10]. Graduates who master the communication skills are the choice of the employer because effective communication can make the organization more developed, competitive and the relationship between the employees and the higher level will also be more enjoyable [44].

In addition, leadership skills are also essential for a graduate to compete for a job. Studies found that employers urgently want employees who can lead themselves and their partners towards achieving organizational objectives, can influence others in carrying out their responsibilities, have the confidence to convince others of the decisions they make and are wise in synthesizing [45]. According to [46], the efficiency of a job depends on the skill of the worker. Therefore, these leadership skills are very important for any organization and graduate who master these skills to have a good chance of getting a job especially in order to face the project-based employment.

Furthermore, graduates who have mastered problem-solving skills are more likely to obtain employment today [22]. This is because most employers require graduates who have critical problem solving skills to work in their company [21]. Employers want graduates who constantly develop critical thinking skills to solve any of their problems such as complex, anxious, formative, analytical, categorical, proposed solutions and finding alternatives to a knowledgeable employee [47]. According to [48], employees with critical problem solving skills can make rational decisions and help plan something more innovative in the interests of an organization.

In addition, teamwork skills are one of the skills employers also value when seeking employment [49]. Teamwork skills are the ability of an individual to work and collaborate with other individuals with diverse social and cultural backgrounds to achieve the same goals [50]. According to [51], teamwork elements are a critical and essential part of the job industry. Teamwork involves a combination of effort, knowledge, skills and abilities that result in higher job performance than individual work and thus improve the performance of an organization [23].

Employers also seek to identify a proactive graduate who can operate the highest skills including analytical, critical, synthesis and communication skills of various ages [25], to facilitate teamwork in the workplace. In addition to making one more innovative, it can also be a catalyst for the transformation taking place within their organization. Therefore, it can be concluded that employability is a skill that must be developed within the individual and acts as a benchmark that determines the ability to compete for employment especially in the face of project-based employment. 


\section{A. The Importance of Employability Skills in Project-Based Employment}

One of the causes of rising unemployment is due to the discrepancy between the employability skills presented by graduates and required by the industry [52]. Employability skills refer to the individual skills or qualities required by industry employers toward new workers when they begin working in the industry sector [46]. Today's students not only need knowledge, but skills in meeting the employability requirements that employers demand.

In [53] study argued that graduates face barriers to obtaining employment due to the demand for certain employability skills elements by the industry as well as the lack of emphasis on employability skills during their studies. Therefore, emphasis on appropriate employability skills is crucial in helping graduates to understand and apply those skills in the workplace especially in the face of project-based employment.

The feedback from the industry revealed that there is a gap between the knowledge, skills and attitudes of the graduates compared to the needs of the workplace [20]. One of the gaps addressed by employers is the inability of Higher Education graduates to master employability skills rather than technical skills [19]. Employers are dissatisfied with the employability skills of graduates in communication, leadership, critical problem solving skills, continuous learning and information management, professional ethics and morals, entrepreneurship and teamwork [14], [21], [22], [23], [24]. Most graduates who fail to get this job do not master the skills of entrepreneurship, especially in dealing with project-based jobs [25].

Among the employability skills that students need is communication skills. Graduates' weaknesses in mastering communication skills acclimatized the situations in finding a job [54]. This is evident when employers often complaining of graduates about their failure to communicate well and smoothly despite their excellent academic achievement [55]. Employers are especially concerned about effective communication skills when it comes to hiring new employees [9]. This level of communication is measured by one's ability to convey an argument with confidence and to provide strong thoughts [48]. Also, the ability to speak fluent languages such as English should also be emphasized. The results of a study conducted by [56] revealed that English speaking proficiency among graduates was low. As technology is becoming more sophisticated in many parts of the world, communication skills among people are an extremely important element in establishing a communication bridge.

Employers also claim that many new graduates lack the critical problem solving skills needed to compete in an ever-changing and competitive world [57]. Teamwork skills are one of the criteria employers need for graduates to obtain high job opportunities [23]. Employers place teamwork skills among the important skills that rank third in the top twenty-one skills or qualities required by employers of their future employees [58]. However, it is found that graduates lack the skills of teamwork making them difficult to find and less competitive globally [23].

The need for skilled workforce in various aspects is now a new issue for graduates to put themselves in the workforce. This is because many graduates are not provided with all the skills required by the industry today [26]. As such, it is time for the university to prepare students with special skills in dealing with project-based jobs so that this widespread unemployment problem can be reduced in the future.

\section{B. Factors Affecting Employability Skills Requirements}

It is discovered that larger companies with more than 200 employees' value employability skills more compared to smaller companies with less than 200 employees [59]. This indicates that the level of employability skills required of an individual who wants to work in a larger company is higher than that of a small company. Interpersonal skills are the most important skills of employers of large companies [22]. Serving clients, utilizing leadership skills and consulting are skills that employers consider most important in terms of interpersonal skills [21]. In addition, the level of employability skills required of an individual looking to work in a private company is higher than that of a public company [19].

\section{CONCLUSION}

Today's challenge demands TVET to train more skilled, innovative, competitive people who are able to adapt in a wide range of industry and employment situations [60]. It can be concluded that employability skills are added value skills that graduates need in improving their quality of life as well as the preparation for employment. Thus, educational institutions and teaching staff contributions and facilitation are important in instilling employability skills among students to ensure the skills they produce are balanced, with quality and meet the needs of the industry.

\section{ACKNOWLEDGMENT}

This research work is a funded research awarded by Research Management Centre, Universiti Tun Hussein Onn Malaysia (UTHM) Johor under Geran Penyelidikan Pascasiswazah (GPPS), Vot No. H330.

\section{REFERENCES}

1. Aleng, P. (2014). Pendidikan Pembangunan Modal Insan. PTS Akademia.

2. Kementerian Pendidikan Malaysia (2015). Pelan Pembangunan Pendidikan Malaysia 2015-2025. Kuala Lumpur.

3. Mion, R. (2018). TVET Lahir Modal Insan Berkemahiran Tinggi Dicapai dari Utusan Online: http://www.utusan.com.my/pendidikan/tvet-lahir-modal-insan-berkem ahiran-tinggi-1.656517\#ixzz5Dju8h4Qs

4. Ito, H. (2014). Challenges towards Employability: Higher Education's Engagement to Industrial Needs in Japan. Higher Education Studies; Vol 4, No. 2; , 1-8

5. Husain, M. Y., Mokhtar, S. B. \& Alias A. B. (2015). Persepsi Pelajar Kejuruteraan Politeknik Terhadap Kemahiran Employability: Satu Kajian Kes. Politeknik Ungku Omar.

6. Yusof, N. \& Jamaluddin, Z. (2017). Pembangunan Kebolehpasaran Siswazah: Tindakan Universiti dan Cabaran yang Dihadapi. Jurnal Personalia Pelajar 20, (2017): 15-32.

7. Rastogi, V. (2017). Labour Contracts: What You Need to Know. A Rashid Publishing.

8. Mallow, M. S. (2017). Beri Peluang Graduan Timba Pengalaman Bekerja. Utusan Online. Universiti Sains Islam Malaysia. Artikel Penuh:

http://www.utusan.com.my/rencana/forum/beri-peluang-graduan-timba -pengalaman-bekerja-1.575413\#i Xzz5jonpAIbc

9. Hanapi, Z. \& Kamis, A. (2017). Analisis Perbandingan di Antara Industri, Pensyarah dan Graduan 
Terhadap Kepentingan Kemahiran Teknikal dan Kemahiran Employability yang Perlu Dikuasai oleh Graduan Bidang Elektrik di Kolej Komuniti. 9: 1-5 (2017) 67-75 |www.sainshumanika.utm.my\} e-ISSN ISSN: 2289-6996

10. Chavan R.R., \& Surve A.Y. (2014). Assessing parameters of employability skills: an employers' perspective. Asian Journal of Management Research Volume 5 Issue 2, 254-260.

11. Mohd Izham, M. H., Juriah, L., Khalid, A., Zaini, M., Hamidah, Y., Zarin, I., \& Rosima, A. (2011). Dalam: Zamri Mahamod, Jamalul Lail Wahab \& Mohammed Sani Ibrahim. Transformasi dan Inovasi dalam Pendidikan. Bangi: Universiti Kebangsaan Malaysia.

12. Yusof, N., Lazim, N. M. \& Jamaluddin, Z. (2013). Persepsi Pelajar Prasiswazah Terhadap Program Pembangunan Kebolehpasaran Siswazah: Kes Universiti Sains Malaysia [USM]. International Journal of Environment, Society and Space, 1(1), 43-61.

13. Baharin, N., Yusoff, I. dan Ismail, R. (2012). Faktor-faktor yang Mempengaruhi Pengangguran di Malaysia. Persidangan Kebangsaan Ekonomi Malaysia ke VII (PERKEM VII). Ipoh Perak. Pp:209-227.

14. Ismail, M. H. (2012). Kajian Mengenai Kebolehpasaran Siswazah di Malaysia: Tinjauan dari Perspektif Majikan. Prosiding Perkem VII, Jilid 2 (2012) 906-913

15. Abdul Hamid, S. (2016). Semakan Semula Pekerjaan Kontrak. Cabaran

16. CUEPACS. (2017). Cuepacs Perlu Bantu Tingkatkan Produktiviti Penjawat Awam. Kongres Kesatuan Pekerjaan Dalam Perkhidmatan Awam.

17. Mamat, M. I. (2011). Masalah Pengangguran di Malaysia: Kesan Terhadap Negara dan Langkah-Langkah Mengatasinya. Universiti Sains Malaysia: Tesis Sarjana

18. Antonino, C., Flavio, U. \& Emanuela, I. (2014). The Relationship Between Contract Type And Job Satisfaction In A Mediated Moderation Model: The Role Of Job Insecurity And Psychological Contract Violation. Volume: 37 issue: 2, page(s): 399-420. SAGE Publications, [2014].

19. Ramlee, M., Mohd Yusof, H., Syed, A. M., \& Seri Bunian, M. (2014) Persepsi Majikan Kejuruteraan terhadap Kemahiran Employabiliti Pelajar Kejuruteraan: Satu Kajian Kes. Journal of Science, Mathematics and Technology (Educatum), Vol.1 No.2, 41- 52.

20. Jabatan Perdana Menteri (2015). Rancangan Malaysia ke-11, Unit Perancang Ekonomi.

21. Ghani, N. A. (2014). Kemahiran Employability dan Penghargaan Kendiri Dalam Kalangan Pelajar Kejuruteraan, UTHM. Universiti Tun Hussein Onn Malaysia.

22. Pua, P. K. (2014). Tahap Kemahiran Insaniah Dalam Kalangan Pelajar Kejuruteraan Tahun Akhir Di Politeknik KPM: Doctoral Dissertation, Universiti Tun Hussein Onn Malaysia.

23. Masud, M. A. (2013). Pembangunan Kemahiran Kerja Berpasukan Menerusi Kursus Pengurusan Kokurikulum Dalam Kalangan Pelajar Sarjana Pendidikan Teknik dan Vokasional UTHM. Universiti Tun Hussein Onn Malaysia.

24. Mokhtar, S. B. (2012). Faktor Persekitaran Pembelajaran, Pendekatan Pembelajaran Dan Kemahiran Generik Dalam Kalangan Pelajar Politeknik. Tesis PhD. Bangi: Universiti Kebangsaan Malaysia.

25. Hashim, N., Kee, C. P. \& Abd. Rahman, M. P. (2016). Mengungkai Isu Journal of Communication. Jilid 32 (2) 2016: 139-164 UNIVERSITI KEBANGSAAN MALAYSIA

26. Andrew, G. \& Russel, M. (2011). Employability skills development: strategy, evaluation and impact [versi elektronik]. Higher Education, Skills and WorkBased Learning, 2 (1), 33 - 44.

27. Arif Nurhadi, M. \& Teuku, T. K. (2014). Pelaksaaan Kontrak Kerja Jasa Kontruksi Mengenai Pembuatan Jembatatan Andalas Padang Antara Perseroan Umum dengan CV. Duta Graha Padang.

28. Mohd Majid, A. (2012). Pemahaman Syarat-syarat Kontrak Pembinaan. Juruukur Bahan. Kontrak dan Juruukur Bahan. JKR Malaysia.

29. Retnosari, I., Budi, L. \& Tri Haryono, A. (2016). Pengaruh Sistem Kerja Kontrak, Kompensasi Dan Career Path Terhadap Corporate Performance Dengan Kinerja Karyawan Sebagai Variabel Intervening. Journal of Management, Volume 2 No.2.

30. Ishak, W. S. (2013). Factors Influencing Construction Worker Job Satisfaction In The Construction Industry. Universiti Malaya. Kuala Lumpur. Tesis Sarjana.

31. Buntat, Y., Rajuddin, M. R. \& Yusof, Z. (2015) Penglibatan Tenag Kerja Tempatan Di Sektor Pembinaan Di Malaysia. Universiti Teknologi Malaysia, UTM Skudai, Johor, Malaysia.

32. (32) Jabar. (2017). Keuntungan \& Kerugian Pekerja Kontrak. Artikel, Kontributor. Bagi Pekerja Dan Kesatuan Sekerja. Memorandum MTUC 2016. Kebolehpasaran Graduan Di Malaysia. Jurnal Komunikasi. Malaysian

33. Praabhu, A. \& Jayam, R. (2012). Motivation Strategy at Work Place. International Journal of Scientific Research 2(4):202-203.

34. Soberi, N. H. (2016). Mahasiswa Digalakkan Cari Pengalaman Kerja Sambilan. Utusan Online.

35. Arif, L. S. (2014). Hubungan Kepuasan Komunikasi Dengan Komitmen Terhadap Organisasi Di Kalangan Pekerja Teknikal: Kajian Kes Di Flextronics International, Senai, Johor. Fakulti Pengurusan Dan Pembangunan Sumber Manusia. Universiti Teknologi Malaysia, Skudai.

36. Sualman, I. (2011). Persepsi Dan Komunikasi: Kesannya Keatas Personaliti, Motivasi Dan Kepuasan Kerja. Shah Alam.

37. Osmadi, A. \& Bookeri, M. (2013). Produktiviti Dan Hubungan Dengan Komitmen Dan Kepuasan Kerjaya Dalam Organisasi Pembinaan. Journal Design And Built.

38. Thanam, B. (2015). Hubungan Sikap, Pemikiran Dan Tingkah Laku Terhadap Keinginan Dalam Pemilihan Kerjaya Dalam Kalangan Prasiswazah Diinstitut Pengajian Tinggi Sekitar Bangi. Fakulti Pendidikan Universiti Kebangsaan Malaysia Bangi. Tesis Sarjana Pendidikan.

39. Beatriz, S., Thomas, H. \& Amparo, C. (2017). Employment Contract, Job Insecurity And Employees' Affective Well-Being: The Role Of Self-Motivation And Collective Efficacy. Open University of Catalonia, Spain. SAGE Publications, [2018].

40. Mohd Yusof, H. (2014). Penilaian Kemahiran Employability dalam Kalangan Pelajar Kejuruteraan Politeknik di Semenanjung Malaysia Tanjung Malim: Thesis PhD. Universiti Pendidikan Sultan Idris (tidak diterbitkan)

41. Mohammed, R. @ U. \& Langkan, F (2018). Isu Kebolehpasaran dan Kebolehgajian Graduan Pra-U Tingkatan Enam di Bahagian Pantai Barat Selatan Sabah. Journal of Global Business and Social Entrepreneurship (GBSE) Vol. 4: No. 10 (January 2018) page 96-105 www.gbse.com.my | eISSN : 24621714

42. Ahmad, S., Ali, N. \& Hamzah, M. F. (2011). Kebolehpasaran Graduan UKM: Satu Kajian Perbandingan Antara Graduan Disiplin Sains dengan Bukan Sains. Jurnal Personalia Pelajar, (14):81-90.

43. Md Nasir, A. N., Ali, D. F., Noordin, M. K. \& Nordin, M.S. (2011) Technical Skills and Non-technical Skills: Predefinition Concept Proceedings of the IETEC 11 Conference, Kuala Lumpur, Malaysia.

44. Nordin, A. \& Ali Mohamed, S. S. (2011). Persepsi bakal guru tentang tahap kemahiran komunikasi berkesan dalam kalangan pelajar tahun akhir Aliran Sains. Latihan Ilmiah, Fakulti Pendidikan, Universiti Teknologi Malaysia.

45. Makhbul, Z. M., Yussof, I. \& Awang, A. H. (2015). Antara realiti dan harapan - Kajian empirical persepsi majikan terhadap prestasi graduan tempatan. Malaysian Journal of Society and Space 11 issue 10 (27-36) Themed issue on Malaysia's human capital - Issues and challenges $(\mathcal{C}$, ISSN 2180-2491

46. Kandar, A. L. (2014). Kemahiran Employability Dalam Kalangan Pelajar Kolej Vokasional Kluang Johor. Universiti Tun Hussein Onn Malaysia

47. Azmi, N. I. \& Mohd Hashim, M. H (2013). Penerapan Kemahiran Insaniah Dalam Pelaksanaan Pendidikan Asas Vokasional: Transformasi Sistem Pendidikan Di Malaysia. Persidangan Pendidikan (Penyelidikan dan Inovasi) Dalam Pendidikan Dan Latihan Teknikal Dan Vokasional (GiE-TVET 2013)

48. Ibrahim, R. \& Ahmad A. R. (2018). Pengukuhan Kemahiran Insaniah Pelajar Tahun Akhir di IPTS: Cabaran Menempuhi Alam Kerjaya Seminar Antarabangsa Isu-Isu Pendidikan. 5 Julai 2018, Auditorium Utama, Fakulti Pendidikan, Universiti Malaya

49. Gallie, D., Zhou, Y., Felstead, A., \& Green, F. (2012). Teamwork, Skil Development and Employee Welfare. British Journal of Industrial Relations, 6(9), 78 - 88 .

50. Mariappan, U., Veloo, A. \& Shanmugam, K. S. (2018). Pembinaan dan Pengesahan Instrumen Kemahiran Insaniah Bagi Subjek Perakaunan di Matrikulasi. Jurnal Kurikulum \& Pengajaran Asia Pasifik; Oktober 2018, Bil. 6, Isu 4.

51. Zainal, N., Abu Bakar, A. A., Nordin, R., Husain, H. \& Mustafa, M. M. (2011). Peningkatan tahap perkembangan kemahiran insaniah mentor melalui Microcontroller School Mentoring Project - Prosiding Kongres Pengajaran \& Pembelajaran UKM 2011

52. Padil, S. (2017). Kerangka Kemahiran Employability Senibina Graduan Politeknik. Universiti Tun Hussein Onn Malaysia.

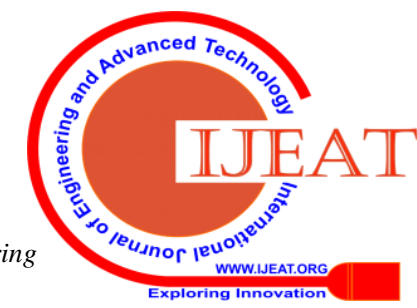


53. Omar, N. H., Abdul Manaf, A., Mohd, R. H., Che Kassim, A \& Abd. Aziz, K. (2012). Graduates"e Employability Skills Based on Current Job Demand through Electronic Advertisement [versi elektronik]. Asian Social Science 8(9), 103-110. Dicapai pada Februari 15, 2015 dari doi: $10.5539 /$ ass.v8n9p103.

54. Mohd Saad, N. N (2012). Kesediaan Pelajar Kejuruteraan UTHM Dalam Aspek Komunikasi. Universiti Tun Hussein Onn Malaysia.

55. Mangkau, I. D. (2012). Penguasaan Kemahiran Komunikasi Dalam Kalangan Pelajar Universiti Tun Hussein Onn Malaysia (UTHM). Prosiding Seminar Pendidikan Pasca Ijazah dalam PTV Kali Ke-2, 2012.

56. Mohd Dazali, N. S. \& Awang, M. I. (2014). Tahap Kemahiran Komunikasi dalam kalangan pelajar sarjana muda pendidikan ipta di utara semenanjung Malaysia. Jurnal Pendidikan Bahasa Melayu, 4 (2): 44-56

57. Abdul Fatah, F.M. (2012, Mac 4). Graduan Tempatan Gagal Tepati Kehendak Majikan. Berita Harian, ms 15.

58. National Association of Colleges and Employers (2011). NACE Research: Job Outlook 2011. Dicapai pada Feb 28, 2013 dari http://www.career.pages.tcnj.edu/file/2011/07/Job_Outlook_2011_Full _Repo rt_PDF1.pdf.

59. Rasul, M. S., Ismail, M. Y., Rajuddin, R. \& Abd. Rauf, R. (2009). Aspek Kemahiran 'Employability' yang Dikehendaki Majikan Industri Pembuatan Masa Kini. Jurnal Pendidikan Malaysia 34(2)(2009):67-69.

60. Saleh, Z., Nordin, M. S., \& Saud, M. S. (2012) Penerapan Nilai Minjaroes dan Formula ' $3 \mathrm{H}$ ' dalam Kurikulum PTV. Journal of Technical, Vocational \& Engineering Education 5(1): 41-55. http://eprints.utm. my/23011/ (16 Mei 2013).

\section{Authors Profile}

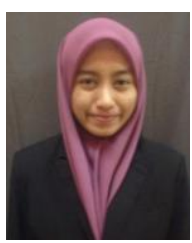

Raudhah Adibah Binti Ahmad Zubir is a postgraduate student in Technical and Vocational Education at Universiti Tun Hussein Onn Malaysia (UTHM). She studied at Politeknik Ungku Omar (PUO) and obtained a Diploma in Civil Engineering in 2014. She then pursued a Bachelor of Vocational Education (Building Construction) degree with honors at Universiti Tun Hussein Onn Malaysia (UTHM) in 2018.

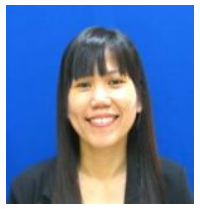

Dr Yee Mei Heong is the senior lecturer for the Department of Engineering Education (JPK) at the Faculty of Technical and Vocational Education of Universiti Tun Husseion Onn of Malaysia (UTHM) She graduated with a Bachelor of Technology in Education (Civil Engineering) with honors at the Universiti Teknologi Malaysia in 2002, and then went on to pursue a Master of Technical and Vocational Education at the Universiti Teknologi Malaysia in 2005. She received a master's degree in Doctor of Education Philosophy Engineering and Vocational at Universiti Tun Hussein Onn Malaysia in 2015. She has teaching experience as a Graduate Educational Services Officer at Maktab Rendah Sains MARA Gerik, Perak for 3 years and a senior lecturer at UTHM for 10 years. She is currently the chair of the Doctor of Education Philosophy Program since 2014. Shee also served as chair of the brick lab in 2014-2016. Her academic expertise includes teaching and learning problem solving skills. She has published over 90 articles / journals / teaching modules / books / book chapters in his area of expertise.

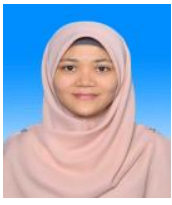

Siti Nur Maizura Binti Sharberi is a postgraduate student in Technical and Vocational Education at Universiti Tun Hussein Onn Malaysia (UTHM). She studied at the Kolej Kemahiran Tinggi Mara (KKTM) and obtained a Diploma in Building Engineering Technology in 2014. She then pursued a Bachelor of Vocational Education (Building Construction) degree with honors at Universiti Tun Hussein Onn Malaysia (UTHM) in 2018. 